\title{
MANAGING INFORMANTS IN HANDLING CORRUPTION BY THE CORRUPTION UNIT OF CRIMINAL INVESTIGATION DEPARTMENT OF LEBAK POLICE RESORT
}

\author{
${ }^{1}$ Fauzy Pratama, ${ }^{2}$ Chairul Muriman Setyabudi \\ ${ }^{1,2}$ Indonesian Police Science College \\ 1fauzypratama13@gmail.com \\ ${ }^{2}$ cak_iir@yahoo.co.id (corresponding authors)
}

\begin{abstract}
Citation: Pratama Frauzy, Chairul Muriman Setyabudi, Managing Informants In Handling Corruption By The Corruption Unit of Criminal Investigation Department of Lebak Police Resort, Management Technology and Security International Journal, pages : 1-10,
\end{abstract}

Received on 1 June 2020, Accepted on 9 July 2020, Published on 1 August 2020

\begin{abstract}
The incapacity of the Indonesian National Police to find out all information on corruption in certain areas and the absence of regulations and laws on using informants in handling corruption need to be solved immediately in order to make sure the handling of corruption cases works effectively. The research attempts to analyze the informant management carried out by the Corruption Unit of Lebak Police Resort and several related factors to the informant management conducted. This study applies qualitative research design by interviewing Lebak Corruption Unit officers and their informants. The research finds out that the informant management system carried out by the Corruption Unit is divided into 4 stages: recruitment, control, utilization, and termination. In recruitment activities, the methods used by the Corruption Unit include (1) persuasive methods, (2) "paid" method; (3) reciprocal method; and (4) coercion method. Meanwhile, based on the Lawrence's Legal System theory, related factors that influence the informant management are the legal structure between Indonesian National Police (Polri) and community, the absence of legal substance related to information management, and the culture of the community that is still 'afraid' of the police. These factors can be both reinforcing and weakening informant management efforts in certain sections.
\end{abstract}

Keywords: corruption, informant management, corruption unit

\section{INTRODUCTION}

The handling of corruption cases has a fundamental difference compared to the handling of other criminal acts. Handling corruption cases is never preceded by a report from the public related to the occurrence of a crime as happen in conventional criminal cases (street crime) so that the police issue police report model B. While in corruption cases, police reports are always in the form of model A which can be interpreted as the police play an active role in finding these criminal acts because there is never a condition where there is someone who feels aggrieved coming to the police office in order to report that corruption cases have taken place 
somewhere. Therefore, in an effort to deal with corruption, it is only natural that the police should master and understand all of the information related to indications of corruption. If the police are not able to gain the information, how they can be able to handle all corruption cases in this country.

However, the problem is whether the police are able to gain all of the information on corruption crime or not. In Lebak Regency, for the period of 20152020 , there were only 2 corruption cases which occurred in 2015 and most recently in 2020. Meanwhile, in the period of 20162019 , it was recorded that there were no corruption cases that occurred in the regency related to these conditions that can be seen in Table 1.

Table 1 Corruption Cases in Lebak Regency

\begin{tabular}{|c|c|c|}
\hline No & Year & Corruption cases \\
\hline 1 & 2015 & 1 \\
\hline 2 & 2016 & 0 \\
\hline 3 & 2017 & 0 \\
\hline 4 & 2018 & 0 \\
\hline 5 & 2019 & 1 \\
\hline 6 & 2020 & 0 \\
\hline
\end{tabular}

Source: Lebak Corruption Unit

Besides, it should be noted that data from the Central Statistics Agency (2019) shows that Lebak Regency is divided into 28 subdistrict and 345 villages. Then, Lebak Regency Government also consists of 22 working units or departments, each of which has a sizeable budget. Thus, how the Corruption Unit of Criminal Investigation Department of Lebak Police Resort can be able to gain all of the information from such a vast region and sector if it is only supported by a limited number of personnel. Therefore, the steps that can be taken by the Corruption Unit are to use and utilize informants related to the matters.

Then, another problem found in the field is that it turns out that the country, Indonesia has not had a system of rules and regulations that regulate in detail the practical realm regarding the use and management of informants conudcted by the police in carrying out police duties, especially in handling corruption cases. The impact of such conditions is that people who actually have the potential to become informants because they have information related to the crimes do not dare to play the role as informants in helping police duties. They do not dare to be informants because they feel that the consequences they will receive when they become informants will be more severe than the attitude of indifference and silence (Dewing and Russel, 2016).

In fact, if the police can use the informants appropriately and build a good informant management system, criminal information related to corruption can be obtained more easily and henceforth can be very useful and support the task of the police in eradicating corruption. The assumption is that if the police can find out all criminal information related to corruption cases that have occurred or are occurring in the jurisdiction, then the police should be able to take actions against these criminal acts. In addition, the police can also take anticipatory measures as a form of prevention so that similar crimes do not recur in the same place with the same modus operandi and opportunities. At this level, Indonesian National Police (Polri) can play greater roles in optimizing the preventive function in preventing corruption. 
Moreover, in the era of industry 4.0, the use of informants should be increased with the use of digital technology and cyberspace, so that a "digital informant" can be established and mainatined that can contribute to assisting the police in providing criminal information related to corruption crimes.

\section{LITERATURE REVIEW}

\section{Typology of Informants based on Motivation}

Along with the development of wolrd police science, four types of informant motives can be identified: hammered informant, mercenary informant, vengeful informant, and police buff. The first type is the most common type of informants, namely hammered informants-people who are "hammered" to comply with. These informants "turned around" or "flipped" after they are arrested and eventually agreed to become informants because of legal pressures.

The second most common type is mercenary informant. These informants are a type of prize hunters who are motivated by money, which the police are more likely to view as greedy then to provide paid assistance. Paid informants usually work on contingency costs, a situation that can be promising and problematic.

The vengeful informant or "vengeful informant" offers to work together to realize revenge against others for certain things, such as the unfair distribution of drug products. There are rumors that the target is trying to accuse friends, berate friends, and feel the competition which motivates a nuance of revenge looking for informants. In general, such informant wants a "fair play" or the condition of being balanced with the target as the reason why he is targeting someone.

The police buff or "police fan informant" is a citizen who basically has a fondness for the police often trying to serve and assist the police duties by acting as an informant which shows that he is useful to the police. Although they may have useful information on certain occasions, they are not motivated by special reasons like other informants (flipped informants, paid informants whose main reason is to benefit materially).

\section{Ethical Climate Work Theory}

Ethical climate work theory is a theory developed by Victor and Cullen (1988) as the development of cognitive moral theory. The dimensions of ethical climate work theory consist of three approaches, namely selfishness, benevolence, and principle. In organizations with egoism characteristics (selfishness), the organizational members tend to consider personal gain when faced with ethical dilemmas. In organizations with benevolence types, the members of the organizations will tend to consider the welfare of others. And in organizations with the type of principle, the members of the organizations will tend to consider matters relating to regulations and laws.

\section{METHOD}

The study employs a qualitative approach with the main methods applied are interviews and document reviews. Interviews are conducted with all members of the Corruption Unit and their informants from various elements of the community (government, NGOs/CBOs, other civil society). Then, at the stage of analysing the research results, the process of qualitative research analysis is carried out from the beginning along with the process of collecting data and field notes that researchers get then categorized based on conceptual or topic similarity. The results of subsequent interviews will be recorded and used as a basis for analyzing and answering the formulations of the issues raised in this study. In order to strengthen the results of the analysis, several interview results will be quoted directly from what was explained by the speakers. 
Furthermore, the results of the research in the field, then interact with other data to strengthen the concepts that have been formed from the results of interviews and observations. Key concepts and theories such as management theory, network formation concepts, Miller's informant concepts, and ethical climate work theory are then compared to other concepts and previous literature studies that have similarities so that they form new concepts or may support previously tested concepts.

\section{RESULTS AND DISCUSSION}

\section{Analysis of Initial Information Sources in the Process of Handling Corruption Cases}

The results of the study illustrate that in general the process of handling corruption can be initiated through three basic methods, namely (1) starting with public information or public complaints; (2) complaints from NGOs (NonGovernmental Organizations) or CBOs (mass organizations) that are fostered; and (3) proactive efforts of the members of the Corruption Unit by utilizing informants in the field. The first source of information is information from the community (public complaints), is juxtaposed with the Miller's concepts (2011). Then, this source of information is included in the informer category. This is because the people who report the indications of corruption to the police only act like someone who conveys information.

Meanwhile, it is different from the two other sources of information, complaints from NGOs or CBOs that are fostered, as well as sources of information from proactive efforts of the members of the Corruption Unit by utilizing informants in the field, are clearly included in the informant category according to Miller (2011). First, information sources originating from NGOs or CSOs that have been fostered by the members of the Corruption Unit can be explained that since before the members of the Corruption Unit have built communication and relations with these NGOs or CBOs. These NGOs and CBOs both have consciously and unconsciously actually been fostered by the members of the Corruption Unit if they already have a sense of awareness and initiatives to provide information related to corruption indications to the police especially if they try to find the information themselves in the field.

\section{Management of Informants of Lebak Corruption Unit}

In its implementation, the management of informants carried out by the members of the Corruption Unit is divided into 4 main parts, namely recruitment, coaching, utilizing, and terminating. In the first stage, direct recruitment efforts are usually carried out by the members of the Corruption Unit when handling a case. In addition, it is also usually done when the Corruption Unit is trying to explore a sector that is indicated by corruption. As an illustration, after there is criminal information coming into the Corruption Unit, the members of the unit immediately respond to that information by crosschecking directly to the field.

Then, while carrying out inspections in the field, the members also are mapping people who are aware of the indications of the corruption. When the informant who provides the prefix information already knows in detail about the corruption, the Corruption Unit members will only use the informant as the main informant without the need to recruit other informants again. Other parties who are aware of the corruption indications will be positioned as witnesses who help explain the criminal events to be handled. However, if the preliminary information provided is incomplete, the members of the Corruption Unit will try to find and recruit other informants from other parties who know the indications of corruption by using various approaches such as:
a. Persuasive method (solicitation)
b. "Payment" method
c. Reciprocal method
d. Coercion method 
The recruitment process as described above is used when the members of the Corruption Unit are conducting an investigation and deepening an indication of a corruption case being handled. However, the recruitment process can also be carried out before the preliminary information is related to the event that is indicated as a criminal act of corruption. This process is aimed at recruiting informants who are able to assist the police in providing preliminary information related to corruption crimes or can also assist the police in helping to search for and provide information when the Corruption Unit is handling corruption cases.

In this recruitment process, the focus of the Corruption Unit in recruiting informants is not to target individuals. They divide the focus of recruitment more into the division of the government sector with the hope that each sector of the police of government already has the informant embedded so that crime information in each government sector can be properly monitored. In addition, the focus is also aimed at every element of society such as the local government sector, community organizations, NGOs, community leaders, and other sectors, where the Corruption Unit also needs to recruit informants from these sectors so that it can monitor various information that develop in particular related to corruption crimes.

The method of recruiting informants carried out before handling corruption cases has little difference from the method of recruiting informants when handling corruption cases, where the recruitment process carried out long before the corruption case appears is more likely to use persuasive methods (solicitation) and "paid" methods. The results found that the members of the Corruption Unit never used the reciprocal and coercive methods at this stage because the typology of prospective informants and the existing situation did not allow the application of the method. However, it is different from the persuasive method (solicitation) and "paid" method in which both methods can be applied to prospective informants who have no connection at all with a corruption case but have the potential to find indications of a corruption case. Prospective informants who are not related to corruption cases do not have a reciprocal relationship with the police and also cannot be coerced legally because their position does not deal with corruption laws directly.

Then, it can be analysed that the informants' motives in Lebak Regency are as follows:

a. Get paid - in this category, someone wants to be an informant because he sees that there will be benefits in the form of some money for what they have done to the police.

b. Trapped in the process of handling processes conducted by the policeanother factor is because they have been trapped in a criminal justice situation. They can include key witnesses who can help explain the corruption case. Or, it can also find parties involved in the corruption case.

Then, the second stage of informant management is the guidance of informants. Guiding informant is an effort made by police officers to control and maintain communication links with the informants. This effort needs to be done so that informants who have been previously recruited remain controlled and well managed by the members of the police force. In addition, this is also useful so that at any time officers need information from the field, they can contact their informants who are scattered in the field so that efforts to obtain crime information can be faster, more effective, and efficient. However, if the field informants are not well managed, the concern is that the members of the Corruption Unit cannot obtain information from the field at any time when they need information because their informants cannot be contacted when they are to be used.

The coaching effort undertaken by the Corruption Unit is by making a list of informants owned. Then, the unit often makes contact and communicates with these 
informants either directly (face to face) or even through other communication media. Efforts to maintain this communication are not conducted on a scheduled and regular basis, but rather tend to be more flexible by adjusting the situation and conditions of the tasks that develop in the field.

Then, the third stage of informant management is the use of informants. The effort to use this informant is to request information related to corruption-indicated events or related corruption cases that are being handled. When the members of the Corruption Unit are faced with a condition that requires the need for information from the field, they will try to contact the informant who is embedded in the relevant sector and then ask the informant for the information. If the informant does not yet have the required information, the members of the Corruption Unit will ask the informant to move to search for information in the field as soon as possible while still being controlled by the members of the Corruption Unit.

Furthermore, the final stage of informant management is the separation of informants. This effort is aimed at stopping communication and relations between officers and their informants, especially in regard to the official implementation of police duties and the binding consequences of each party. There are several conditions causing the need to terminate the informant. First, the work of the informant has been completed and he or she is considered no longer needed (usually the recruitment of informants is devoted to handling certain cases only). Second, the informant was not active in working to find and provide information to the police. Third, the informant has been indicated to have defected and has the potential to pose threats to the police.

\section{Factors Influencing Management of Informants}

The results show that there are two main factors influencing the management efforts of informants in the process of handling corruption cases. The first is the absence of a legal basis for the members of the Corruption Unit (investigators) in the management of informants even though these activities have often been carried out and become the core of the activities in the process of handling corruption cases. As a result, the members of the Corruption Unit do not have a strong legal umbrella in acting and tend to 'speculate' on police actions taken. In the end, it will return to the Head of Anti-Corruption Unit that is leading, whether he dares to take steps and decisions related to every informant management effort made in order to successfully deal with the corruption cases that are being faced. If the Anti-Corruption Unit Head is brave to take steps, then the efforts of informant management will be more intense, although there are legal consequences in the "gray" realm encountered. And conversely, if the AntiCorruption Unit Head does not dare to act, then the performance of the AntiCorruption Unit will tend to "go in place" and there is no progress because the absence of a legal basis is hampering the performance of the Corruption Unit.

Then, the second factor influencing the management efforts of informants is in terms of community culture in the Lebak Regency. On the one hand, this culture is an obstacle in approaching the members of the Anti-Corruption Unit to the community. But, on the other hand, it also facilitates the performance of officers because the community in certain situations becomes more open and easy to provide information to police officers.

\section{CONCLUSIONS}

The conclusions obtained from this study are as follows:

a The informant management system carried out by the members of the Corruption Unit of Lebak Police Resort Criminal Investigation Department is divided into 4 stages: recruitment, control, utilization, and termination of the informants. In 
recruitment activities, the methods used by the Corruption Unit include (1) persuasive methods - solicitation, (2) "paid" method, (3) reciprocal method, and (4) coercion method. Meanwhile, fostering informants is an effort made by police officers to control and maintain communication links with informants. Then, the activity of using informants is an activity of mobilizing informants by the Corruption Unit in order to obtain information needed in handling corruption cases. And finally, the activity of terminating the informant is carried out if one or more of the following conditions are found, (1) the work of the informant has been completed; (2) informants are not active; and (3) the informant has been indicated to have defected and has the potential to pose threats to the police.

b. When viewed from the legal system component of Lawrence $\mathrm{M}$. Friedman's theory, the factors that influence the management of informants carried out by the Corruption Unit are that there is no legal substance that regulates how the police provide legal protection for informants who have worked for the police in the legal process undertaken. In addition, another factor is the culture of the community's fear of the police.

\section{IMPLICATIONS}

The results of the study recommend the following things:

a. At the practical implementation level, the results of this study can be used as a reference in implementing tasks in the field. Moreover, in the era of industry 4.0, Polri can develop digitally-based information management systems so that they could bring up "digital informants."

b. Then, at the level of strategic implementation, Polri needs to draw up regulations that concretely explain techniques, tactics, and methods in providing legal protections to informants who have worked for the police and how they will go through the legal processes.

c. For further research, it is recommended to use strong quantitative data and methods so that they can cover up the weaknesses related to data quantification in this study.

d. Besides that, the limitation of this research is that this research is only reviewing the informant management design by referring to the existing concepts and rules, without reviewing the effectiveness of the rules and concepts. Thus, it can be suggested that further research needs to examine the effectiveness of the existing rules and concepts.

\section{REFERENCES}

Ahmad, S. H., Buniamin, M. A. A., and Mahali, M. F. M., 2015, "Ethical Reasoning as Contextual Predictor of Whistle-Blowing Intention", Journal of Administrative Science, 12 (1), pp. 3546.

Ahmadi, R. 2014. Qualitative Research Methodology, Yogyakarta: Ar-Ruzz Media.

Andi Hamzah. 2007. Comparison of Corruption Eradication in Various Countries, Jakarta: Sinar Grafika. 
Anthony Minnaar, 2011, "The Use of Informers: an Essential Tool in the Fight Against Crime?" Southern African Journal of Criminology, 24 (3), pp. 83-97.

Asbury, B., 2011, "Anti-Snitching Norms and Community Loyalty", Oregon Law Review, 89, p. 1257.

Central Statistics Agency, 2019, "Central Statistics Agency of Lebak Regency", on line: https://lebakkab.bps.go.id/, accessed on 25 September 2019.

Brown, D., 1994, "Notes on the Culture of Prison Informing", Current Issues in Criminal Justice, 54 (5).

Colin Atkinson, 2019, "Mind the grass! Exploring the assessment of informant coverage in policing and law enforcement", Journal of Policing, Intelligence, and counterterrorism, 14 (1), pp. 1-19.

Cullen, J. B., Parboteeah, K. P., and Victor, B., 2003, "The effects of ethical climates on organizational commitment: A two-study analysis", Journal of Business Ethics, 46 (2), pp. 127-141.

Curriden, M., 1995, "The Informer Trap: Secret Threat to Justice", National Law Journal, 17, pp. 1-4.

Databoks, 2019, "Up 1 Point, Indonesian Corruption Perception Index Ups to 4th in ASEAN", in databoks, online: https://databoks.katadata.co.id/datapubl ish/ 2019/ 01/29 /ascending 1- pointindex-perception-corruption-Indonesiaup-to-rank-4-in-ASEAN, accessed on 25 September 2019.

Dewi, Santi, 2019, "Indonesia's Corruption Perception Index in 2018 Only Increases by One Point", in idn times, online: https://www.idntimes.com/news/Indon esia/santi-dewi/index-perceptioncorruption-Indonesia-2018-ride-onepoint / full, accessed on 27 September 2019.
Dewing, I. P., and Russell, P. O., 2016, "whistle-blowing, governance and regulation before the financial crisis: the case of HBOS", Journal of Business Ethics, 134 (1), pp. 155-169.

Dorn, N., Murji, K., and South, N. 1992. Traffickers: Drug markets and law enforcement. London: Routledge.

Primary Fauzy. 2018. Investigation of Crime \& Detective Culture. Bandung: Echo of Scholars.

Fitzgerald, D, 2007, Informants, and undercover investigations: A practical guide to law, policy, and procedure. Boca Raton, FL: CRC Press.

Friedman, Lawrence M. 1975. Legal Systems: Social Sciences Perspective (M. Khozim Translation). Bandung: Nusa Media Publisher.

Goddard, D. 1988. Undercover: The secret lives of a federal agent. New York: Times Books.

Grosman, B. 1969. The Prosecutor. Toronto: Toronto University Press.

Gustavo Fondevila, 2013, "Controlling the Madrinas: the Police Information Management and Control System in Mexico", The Police Journal, 86, pp. 116-142.

Haglund, E., 1990, "Impeaching the Underworld Informant", Southern California Law Review, 63, pp. 14071447.

Harney, M.L. And Cross, J.C. 1968. The Informer in Law Enforcement. Springfield, Illinois: Thomas.

Hasanudin Aco, 2017, "SEMA 4/2016 Must Be Followed by All Judges as a Guide to State Losses", in Tribunnews.com, online: https://www.tribunnews.com/nasional/20 17/03/13/sema-42016- must-be typedutiwhole-judge-as-guidelines-about- lossstate, accessed on 29 September 2019. 
Hogg, R., 1987, "The Politics of Criminal Investigation" in Wickham, G. (Ed.) Social Theory and Legal Politics. Sydney: Legal Consumption Publications.

Hughes, G., 1992, "Agreements for Cooperation in Criminal Cases", Vanderbilt Law Review, 45 (1).

J. Mitchell Miller, 2011, "Becoming an Informant", Justice Quarterly, 28 (2), p. 203-220.

KNKG. 2008. Guidelines of the System of Reporting Violations-SPP (Whistleblowing System-WBS). Jakarta: KNKG.

Lavena, C. F., 2016, "Whistle-blowing: individual and organizational determinants of the decision to report wrongdoing in the federal government", The American Review of Public Administration, 46 (1), pp. 113136.

Lukman, Agus, 2017, "Community Policing or Community Policing, What Is It?" 2019.

Madinger, J., 1999, Confidential informant: law enforcement's most valuable tool. Boca Raton, FL: CRC Press.

Supreme Court, Supreme Court Circular Letter Number 4 of 2011 concerning Treatment for Reporters of Criminal Acts (whistleblowers) and Witness Actors who Cooperate (justice collaborator) in Certain Crimes Cases.

Manning, P. K. 2004. The narcs' game: Organizer and informational limits on drug law enforcement (2nd edition). Prospect Heights, IL: Waveland Press.

Moeljatno. 2008. Criminal Law Principles, Jakarta: Rineka Cipta.

Moleong, Lexy J. 1989. Qualitative Research Methodology, Bandung: PT. Teen Rosdakarya.
Natapoff, A., 2004, "Snitching: The Institutional and Communal Conferences", University of Cincinnati Law Review, 73, pp. 644-703.

Novrieza Rahmi, 2017, "Who is Authorized to Declare State Losses? SEMA is not binding", in hukumonline.com, online: https://www.hukumonline.com/berita/ba ca/lt58ac1253a9228/who-authorized-to declare-state-loss-at-any-non-binding, accessed on September 29, 2019.

Peter N. Grabosky, 1992, "Prosecutors, Informants, and the Integrity of the Criminal Justice System", Current Issues in Criminal Justice, 4 (1), pp. 47 63.

Pfuhl, E. H., Jr., 1992, "The legitimation of snitching", Justice Quarterly, 9 (3), pp. 505-528.

The Republic of Indonesia, Law Number $7 / 2006$ concerning Ratification of the United Nations Convention Against Corruption, 2003 (United Nations Convention Against Corruption, 2003).

The Republic of Indonesia, RI Law Number 13/2006 concerning Protection of Witnesses and Victims.

The Republic of Indonesia, Republic of Indonesia Law Number 20/2001 Concerning Amendments to Law Number 31/1999 concerning Eradication of Corruption.

The Republic of Indonesia, Republic of Indonesia Law Number 31/1999 concerning Eradication of Corruption Crimes.

Reuter, P., 1983, "Licensing Criminals: Police and Informants" in Caplan, G.M. (Ed.) ABSCAM Ethics: Moral Issues and Deception in Law Enforcement. Cambridge, MA: Ballinger.

Rich, M., 2010, "Coerced Informants and Thirteenth Amendment Limitations on the Police-Informant Relationship", Santa Clara Law Review, 50 (681), pp. 689-690. 
Robert Klitgaard. 1991. Controlling Corruption, Berkeley, University of California.

Roger Bilingsley, 2001, "The Police Informer / Handler Relationship: Is It Really Unique?" International Journal of Police Science \& Management, 5 (1), pp. 50-62.

Rohmaida Lestari and Rizal Yaya, 2017, "Whistle-blowing and Factors Affecting the Intention to Implement It by the State Civil Apparatus", Journal of Accounting, 21 (3), pp. 336-350.

Rosenbaum, D. P., 1989, "Enhancing citizen participation and solving serious rime: A national evaluation of Crime Stoppers programs", Crime \& Delinquency, 35, pp. 401-420.

Rosenfeld, R., Jacobs, B., \& Wright, R., 2003, "Snitching and the code of the street", British Journal of Criminology, 43, pp. 291-309.

Simons, M., 2003, "Retribution for Rats:

Cooperation, Punishment, and

Atonement," Vanderbilt Law Review, 1 (56), pp. 28-29.

Skolnick, J. H. 1966, Justice Without Trial: Law enforcement in a democratic society. New York: John Wiley.

Skolnick, J.H. 1975. Justice Without Trial: Law Enforcement in a Democratic Society. New York: Wiley.

Soekanto, S. And Mamudji, S. 2011. Normative Legal Research A Brief Review, Jakarta: Raja Grafindo Persada.

Sugiyono 2013. Qualitative Quantitative Research Methods and R\&D, Bandung: Alfabeta.

Terry, George R. 1984. Management Principles (Translation by J. Smith, D. F. M), Jakarta: PT. Earth Literacy. 